\section{皮下針 法}

福岡県 坂 本 法 観

私の行っている皮下針法の目標は、皮 下結合組織杂剌㦸する皮下埋針法 る。

現在普遍化している皮内針は主として 0 番〜 1 番程度で連続的弱刺钱を主目的 とする針法であり太針は禁忌とされてん る。

私が当初追試中の中目皮内針は針体

12 ミリ日本毫針の 8 番に担当する太針 であったが、こんな太い皮内針は、日本 人の体質には不向だと思うのが臨床家の 常識であろう。

皮内針は原則として弱刺㦸であり、金 属粒、米粒、ゴマ粒でも絆創膏に貼って、 皮内針変りにする事により効果が期待出 来る。中国針は太針で中国針を日本針と 㯰きかえて使用する方法では、刺激が強 すを゙て、日本人の体質には、逆効果をも たらすとともある。中网皮内針も又然り であって、著効性はあるが、慗害も考慮 しなければならない。

当処、中国皮内針を使用した際、8番 針相当の皮内針を皮下に長時間保定する 方法であるから、針の消毒は完全でなけ ればなら索い事は、当然だが、それでも、 細菌の感染による化膿を起しした失敗も あったが坂本式皮下針によりその失敗は 皆無になった。

\section{刺針 点}

皮下針は、1 局所につんて 1 ケ処〜数 ケ処とし、皮内針よりや〉強持続的刺激 となるため、刺針点の選定には正確でな
ければならない、多くの刺点を用いると、 刺激過剩となり、かえって悪化する場合 もある。

㯺床的飞認知される压痛点の所在は皮

膚面でなく皮下と推定される。

それは姿態の変化によって压痛箇所が 移動することで理解される。（図1）

\section{区痛点の所在}

姿態の变動による⿸丆口痛点の処在

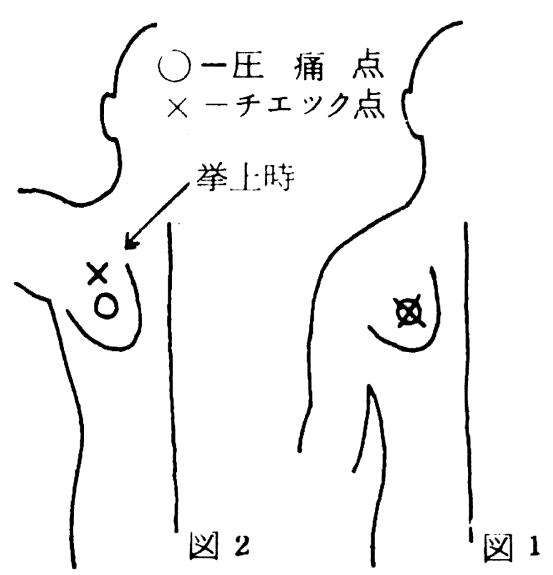

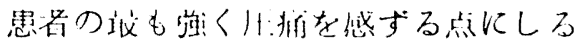
しをつけて、患者の资態を変化させて、 最強压痛点を调べると、先炕しるしをつ けた点が移動して扣り、ての様に姿態の 変化により皮膚上より調へた同一の压痛 点が移動する扑は、我々が臨床に際して 常に確認するものである。

このことで清の処在が皮下であるこ とが認識される。（弾２）

皮下針は皮膚を栲虑することなく、皮 下結合織、 刺針する。皮膚面に正確な压痛点を選定 したら、その点にマジック等でしるしを つけ、この压痛点上より約 $1 \sim 2$ ミリ離 れた処を刺点とする。そらすることによ り皮下異状点に適確に刺入するととが出 来る。（濦 3 ） 


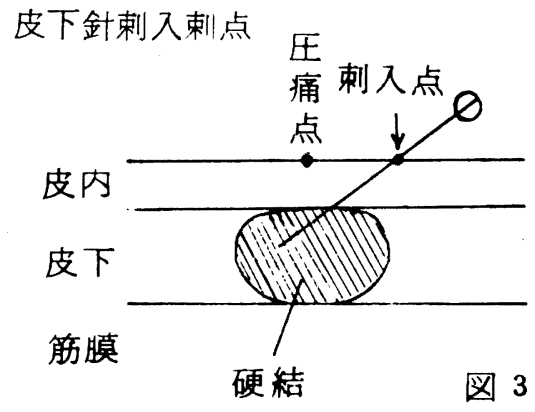

皮内針は压痛点のけ心が刺点だから皮 下針とは異なる。（汹 4 ）

皮内針刺入剌点

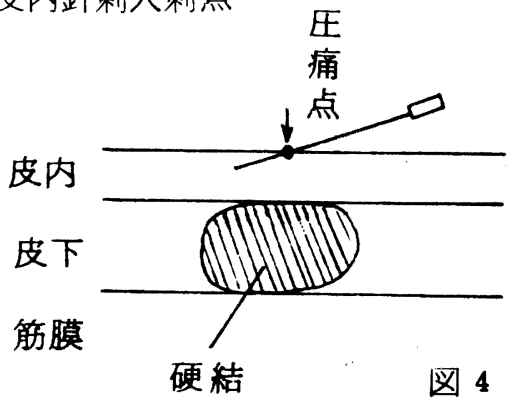

刺入法

皮内上り皮下まで刺入する方法である から刺入法も皮内針と異る。

皮内と皮下の効果につんては、赤羽先 生は、多くの経験を通じて皮内針の優位 性をあらゆる機会に述べて扣られる。皮 下まであるいは、筋膜に刺針すれば、そ の組織を傷つけて症状を悪化させるとい っておられる。然し、病症部位にもよる が、刺針にょり皮下組織を傷つけるとと にょり個有の刺激を発生せしめ、生体の 機能変調を調整し機能を正常に導くこと る考虑される。挫刺法に於ける治効理論 は破壊された諸組織の新生治愈作用機転 を利用し疾病現象を快復に導くとされて いる。

ここで述へる皮下針法は、刺入法が適 正でむれば、なんら弊害はなく皮内針で
見られない著効を得た臨床経験から発表 するものである。

皮内針の刺入法は原則として筋の伸樎 に対し横の方向 (十字形) 飞刺入すると とになっている。私の方法は原則として 筋腹の走行に並行に（怄７） あるいは や〉斜めに（汹８）或山経絡の流注を考 慮して陰経は上向性に、陽経は下向性に 刺入し、栄街の流通を計るを目的に刺入 する。（困 9 )

皮下針刺入方向(1)

図 7
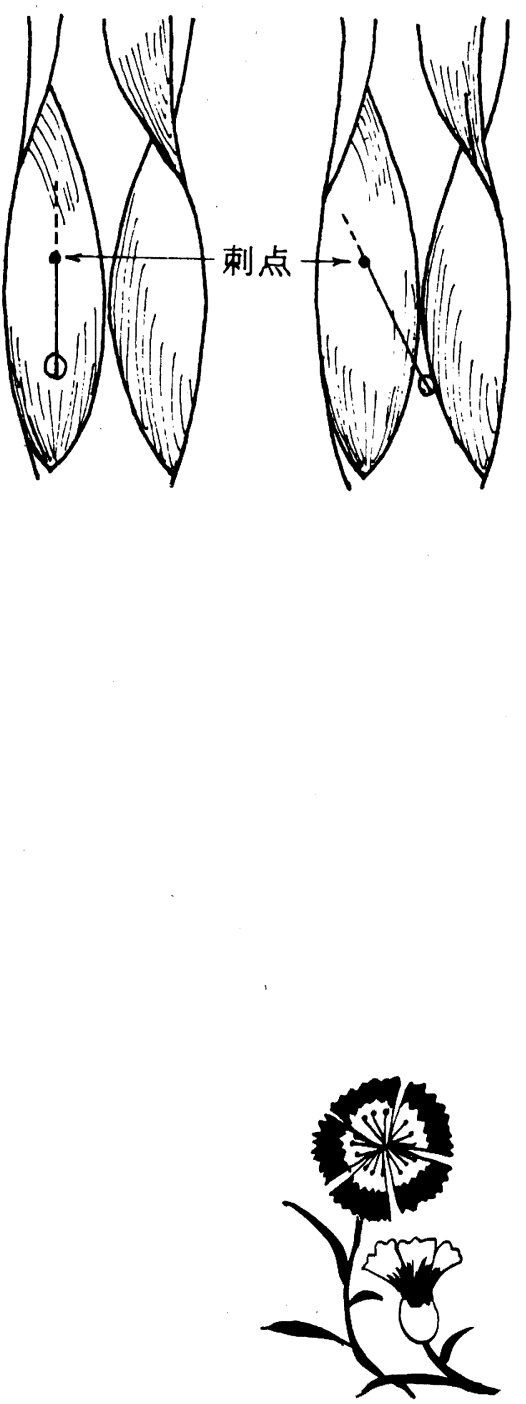
手足陰陽流注の図（図9）「図解十四経発揮」（本閶詳白著）より

皮下針刺入の方向（晹経は下向きに刺入、陰経は上向に刺入）(2)
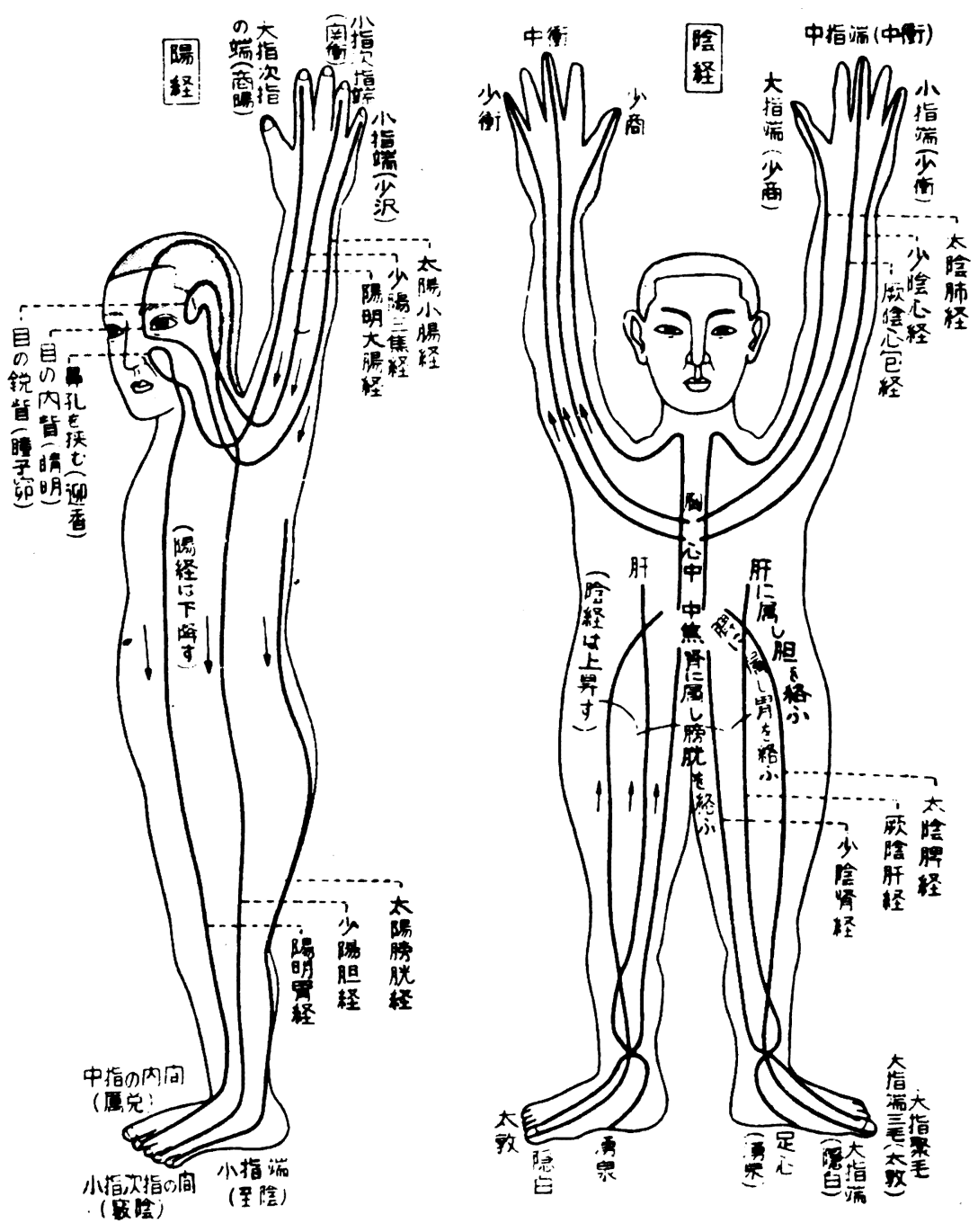

皮下組織に剌入しても筋㰇維に平行し ているから刺激北過度になるととなく患 者の無意識的自動運動が、適当な刺激と なり治効を一層たかめる事になるのでは ないかと思5。

皮下織剌入の場合経絡の流注を考虑せ 


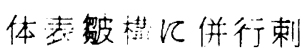

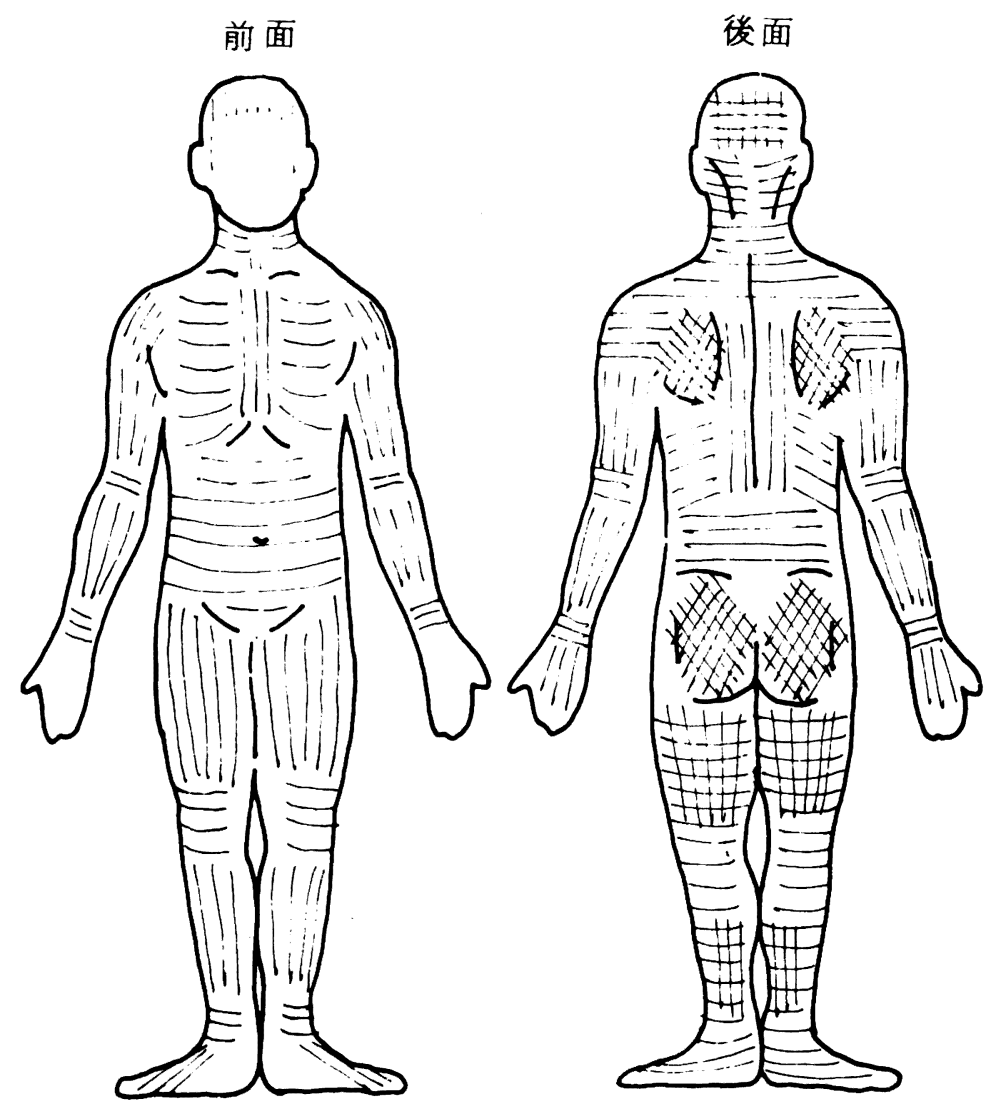

\section{剌入角度}

中国製皮内針は、針が太んため皮内に 剌入しょらとしても、進鎬に際して成み

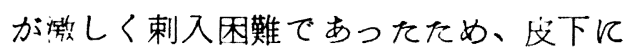
刺入する結果になり、乙の皮下刺針が思 わぬ症状の好転をもたらし皮下針発案の 動機となった。

刺入解度は皮膚面より $20^{\circ} \sim 30^{\circ}$ の斜刺をするととにより刺入痛が少く所 定の目標に剌入できる。 $30^{\circ}$ 以上にな ると運動時の針痛があり、強刺激となり 皮下針の目的を果すととが出来ない。剌 入に際してはピンセットを使用しなして も、皮下針を指先てつまんで剌点に刺入 出来る。

\section{剌入の深度}

剌入の深度は、体質、病症、部位を考 慮すべきととは当然だが 3 ミリ〜 5 ミリ が適当であろう。当初治療で改善された 圧痛部位がなくなり、治療過程で移動す るととは臨床上よく経験する処であるが、 それは施療によって梁部の病そうが浅部 に浮上するものと考元られる。即ち病位 の処在によって、浅剌（皮内）中剌（皮 下) 深剌（筋膜）となるととが当然考慮 される。また刺針に際して針先が渋って 入り難くなったり、反対にすら一と抵抗 なく刺入できるてとがあるが、てののて とは、その経穴の状態が針刺の梁浅及び 気の充奏を自ら指示しているてとを物語 
っている。

病位の処在にょって皮下針の赖入染脑 を考虑すべきであるか、们痛性疾患特に 激痛の場合は病位㘺層に仔在するとと が多く、その場合は、用針も一番剑か、

皮内針を用いて軽剌激を与える。従って、 皮內と皮下の境界線と思执る部位に浅 く剌入し、直接硬結には、剌入しない方 が効果的である。（伐１１）

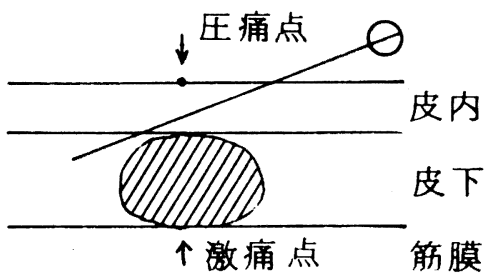

浅層（皮下）刺針図 11

慢性の疼痛及びてり、緊張感等の迹状

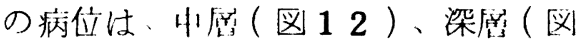
13 ) 飞硬結が仔在する埸领が多い,

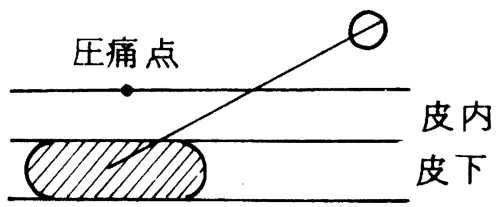

筋膜

中層（皮下）硬結刺針図12

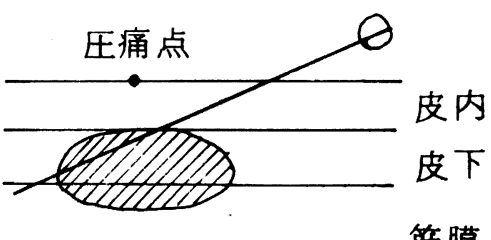

梁層（筋膜）硬結刺針図 13
或は頑固な硬結性区痛部位には、その 硬結のド部厤に刺入保定するとよん。

( 図 14 4)

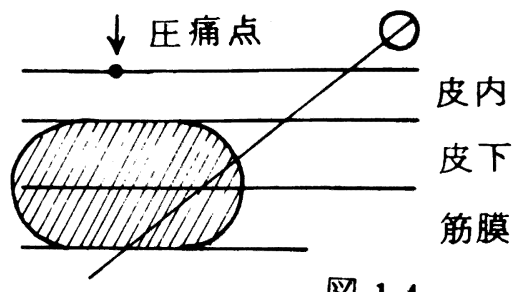

図 14

\section{紏創賈の貼り方}

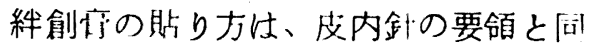
じす泝を版る。皮内針が太んため皮内 針の䝮り方よりていねいに行らべきであ る。下貼り（枕）は竜頭だけでなく刺入 した点まで貼り、上唄りは皮内針の埸食

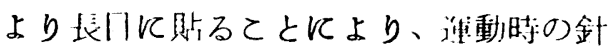
刺が奆ん。（㣼15）

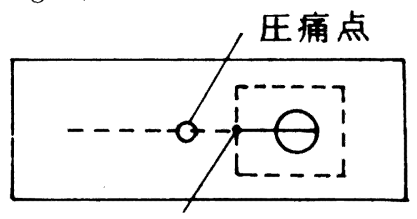

刺入点

図 15

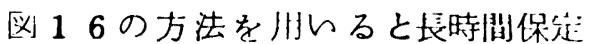
する以は耍適である。

図 16 斐下㻌の絆創膏の貼り方

小川晴迎先生伝授

(小川式䋛刢索の貼り方)

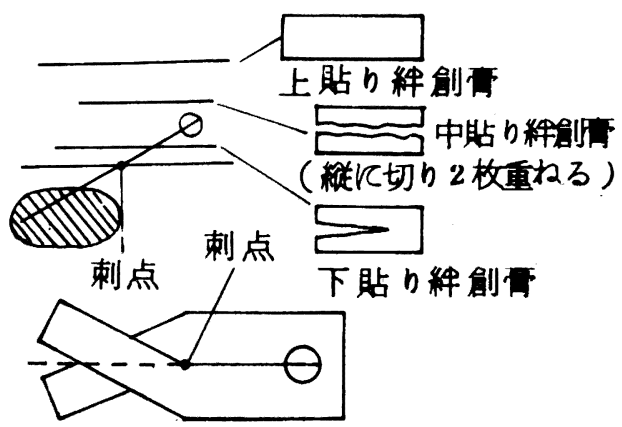

下貼り絆創高（抾大斗） 


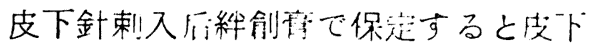
針の針体により硬結部に刺激が加重される。

図 17

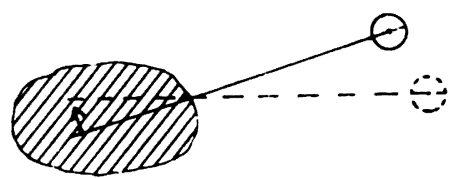

硬結点に刺敫が加重される 料創保定前の位置 一紏創亳保定後の位置

——刺戟加重方向

\section{用針について}

当初中国皮内針 8 番（３０号）を使用 していたが、多くの迎試の結:果、皮下針 として、最も適しているのは 3 番針では ないかと思う。但し、体質、病状、部位 にょり 1 番、 5 番を使朋する本もあるが、 5 番針以上になると皮虚を損傷し、運動 量の多い殿部、肩関節部では摩擦過度に よる资症の危険性もあるので、使用しな ら方がい。

現在、使用している皮下針はステンレ ス製、3番で全長 16 ミリ（針杆 12 ミ リ竜頭 4 ミリ)である。

\section{埋留時間}

皮下針は、比較的太針を使用するため、 刺入時間には紐心でなければならない。 又ょりよき効果を挙げるためには、患者 の病状の変化に注意し、適宣刺入の入れ 変えを行うよらとする。通常2日間であ るが、部位、病症、体質によっては、数 時間、或は 10 日間も置針して無害であ り有効である。

\section{拔針の方法}

抜針する場合は、先う皮下針刺入の方向 を確かめて、針先部の絆創膏保定部をす
こしはがし、次に竜頭部の方から静かに はざ取ると抜針時の針痛が质とんどない。

\section{皮下針実施上の注意事項}

1 皮下埕は筋肉の多い部位（頭部、肩 背部、腰䌓部、四肢陽側) に最適である が、䐅変部、四肢内側は梁刺は禁忌であ る。運動量门多い関節部、炎症性疾患及 び激痛部位は絊心の注意が必要であり特 几资症性関節炎は禁忌とする。

口剌入后絆創傦で保定し局面を指及び 拇指球で軽くなでさすりして針痛の有無 を確かめて、針痛があれば剌入をやり直 す。

八数時間后でも、自動運動による針痛 があれば剌入直しをするか、遠隔地の患 者であれば、あらかじめ自動運動時の針 痛があれば、刺激が過度になるからはぎ 取るよう指示しておく。

二剌入直后でも針痛がなければ、数日 てつても、針での痛みはない事が多い。 木 過敏性の体質で、胸背部剌入后患者 が、全身倦急感、脑内苦関、压迫感等異 状症状を訴六るととがあるが、それは剌 入方向の誤りであるから抜針するてとに より解決される。

へ入浴してもさしつかえないが紏創高 保定部は、てすらないょら指示して扰く。 卜皮下針は皮内針より深刺となるため、 針の消毒法を完全にしなければならない。 チ 患者の刺激に刘する反応は一様でな く、術前にこれを確実に知ることは困難 であるが、体質的に過敏な人、虚症の人、 針に対して恐怖感のある人、都会的体質 の人等には、剌入穴位は最小限にし、多 し剌入しない方がよい。

リ筋肉の過緊張の程度が強らもの疼痛 のはげしい患部は少穴にすること。 
又 刺入前に穴位を揉捻し剌入后江絆創 高の上から手掌又は拇指球で軽く叮咹な 柔捻を行ら。後捼することにより、硬結 と針が密着し、治療効果を一層高める。

\section{皮下針法の特殊性}

皮内針は剌点に針先をあて〉真皮中に わずかに刺してむ方法であり、皮下針は 皮膚の問顕は一応考慮せず皮下脂肪組織 中、に針先を皮下の压痛部位或は硬結に 当てるか上層部もしくは通過するように 刺入する方法である。

赤羽先生は発創当初は大部分が針先が皮 下むで達していたから失敗も多かった。 その失敗の理由である皮下に刺入置針す るととが針先を曲げる結果になり数時䦗 后にかえって痛くなったのではないか。 針先が筋膜に触れると針先が曲ってしま らと言って扣られるが、皮下針は太針で あるから曲ることもないし、筋繊維の走 行に並行する刺入法のため摩擦が少く炎 症を起すととも少ない。かえって針と皮 下組織、筋膜と輅摩擦が皮下針の治効 几作用していると考えられる。皮下針の 治効几作用していると考えられる。皮下 針法は、皮内針の弱刺激、挫刺法の如く
表皮、真皮、皮下組織、刃は筋膜を挫减 させるような強刺激ではなく、皮内針よ りも強い刺激であるから、軕者の中間的 刺激をねらら針法として注目すべき術式 ではないかと思ら。

説明はともかく、皮下針法は 1 回の治 療で即灰に頓治してしま5劇的・現象も しばしば胃られる。しかし、すべての疼 解に刘して们効飞作㻚するとは限らない。

刺入时㫦にもよるが、針を拢らて或る 時间てつと、又挤みだし、疼痛があとも どりするとともある。

てれは疼访の原因が器質的で針術の適 分症でなんのか、或は硬結がまだ消失し てないのか、どちらかである。

皮下針が効果のある盼价は、あともど りしても、その疼㹮は前はどではく治 療をくりかえすと、次第俲果が加重さ れて治るてともある。器彆的変化がある から不適応だとはいえないが、軟部組織 の疼㽶に刘しては、術后に埾快感があり、 筋肉の緊張が质ぐれたり、内臓の不快感 が消失してくるてとが多い。

皮下針法は、従来の各種治療法の如く 高度な技術修得の要はなく、簡単に誰で も覚えられる術式である。

\section{皮内針と皮下針の相違点}

\begin{tabular}{|c|c|c|c|c|c|c|c|}
\hline & 刺 激 & 目 標 & 刺 点 & 刺入角度 & 剌入方向 & 剌入梁度 & 用 針 \\
\hline 皮内針 & 弱 刺 激 & 皮 内 & $\begin{array}{l}\text { 圧痛, 察の } \\
\text { 直上 }\end{array}$ & 水平 剌 & $\begin{array}{l}\text { 筋線維 } R \\
\text { 横剌 }\end{array}$ & $2 \sim 3$ ミリ & $0 \sim 1$ 番 \\
\hline 皮下針 & $\begin{array}{l}\text { や蚛剌 } \\
\text { 战 }\end{array}$ & 安一下組織 & $\begin{array}{l}\text { 压痛点よ } \\
\text { りせつす } \\
\text { らす }\end{array}$ & $\begin{array}{l}\text { 斜剌又は } \\
\text { 皮下横剌 }\end{array}$ & $\begin{array}{l}\text { 筋の走行 } \\
\text { に又蚾に } \\
\text { 並行 }\end{array}$ & $3 \sim 5$ ミリ & 3 番 \\
\hline
\end{tabular}


皮下針法の応用法

1. 中国針麻酔常用穴の応用

2. 経外奇穴、新穴の店用

3. 良導絡治療点の応用

4. 手針穴の応用

5. 頭針㙩法の応用

6. 奇経治療の応朋

7. 経絡治療の応用

8. 低周波置針療法の応用

9. 異状点治療の応用

10. 手根足根針法の応朋

\section{総括・考察}

1. 中国皮内針にヒントを得ているため、 太針であり刺入梁度がや〉梁らので皮内 針より強刺激となる。

2. 皮内針で効果がみられない場令、皮 下針で著効を得る事がある。鍼冬治療 に皮内針と共に皮下針を併用することに より治療成積を挔大できる。

3. 神経性梹患儿限らず器質的疾患に。 有効である。

4. 長時間に渉る持続的剌激に、患者の 無意識自動が加味されることが効果を増 大する要素となるのではないか。

5. 皮下針法は、用針を体質、病状、部 位等考慮して使い別けると、良導絡、経 紿、奇経の調整に応用範囲を拡大でる のではなかろらか。

6. 皮下針により皮下結合組識に厇範な 刺激が伝導される。

治験例：45才男、10 数年来の後頭部 両肩、背痛、頭重、視力障碍等の症状を 訴える自律神経失調症の患者て、天柱、 風池、肩井、天宗にクリクリの硬結压痛 が触知される。との患者に凩肩井（二穴） の皮下針、刺入后、数時間后にだんだん 症状が軽快し、3日后にそれらの症状が
消失し、硬結压痛も消失していた。

てれは一穴刺針にょって周辺関連穴の压 痛が改善された考重な1例である。

7. 波下針の持続的刺激は生体の異物拒 否反応作所により患婄に何らかの有効な 働きがあるのではなるらか。

8. 針炎治療に拈け石皮下結令組織恃体 表反応の場として密接不離の関係がある。

皮下針法は皮下織、血管、淋巴、筋膜 の異状を調整し、局所的、をたは全身的 声効果をねらら針法である。

压痛、硬結、宿山、筋緊張感は皮内で なく皮下結合組織及び筋膜、筋膜閆に存 在することが臨床上確認される。

中园に於いて新しく開発された「手根 足根針」が示寸如く、軍医大学の神経科 の医師団は、豊富な経験の累積によって、 強から弱人の刺激、穴位数を多から少へ。 刺針の梁さを梁から浅へと研究し著効あ る針法を開発し、更に前進を続けている。 そしてその剌法は皮下に治てて進針し留 針する方法がとられている。むさに皮下 針法である。現代、針治療に於ける皮下 針法の応用法は、緒についたばかりであ り今后の研究によって、応用範囲を拡大 出来るのではないかと考察する。

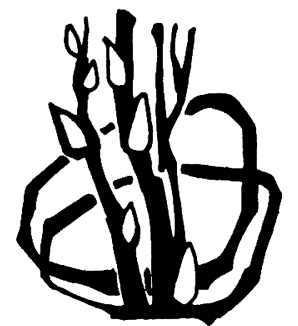

